\title{
An Empirical Study on the Default Prediction Model in Small and Medium-Sized Enterprises Using Financial Ratios
}

\author{
Changyong Yang ${ }^{1} \&$ Yen-yoo You ${ }^{1}$ \\ ${ }^{1}$ Dept. of Knowledge Service \& Consulting, Hansung University, Seoul, South Korea \\ Correspondence: Changyong Yang, Dept. of Knowledge Service \& Consulting, Hansung University, Seoul, South \\ Korea. Tel: 82-10-6298-2735. E-mail: dreamer0401@ hanmail.net
}

Received: April 9, 2020

Accepted: May 9, 2020

Online Published: May 23, 2020

doi:10.5430/rwe.v11n2p129

URL: https://doi.org/10.5430/rwe.v11n2p129

\begin{abstract}
Background/Objectives: There were many studies and empirical analysis of the default prediction model using the financial ratios of large companies, such as listed companies, but despite the large impact on the national economy, there was not much research on small and medium-sized enterprises due to lack of data, and it was also limited. Therefore, we studied the default prediction model of small and medium-sized enterprises through empirical analysis.

Methods/Statistical analysis: The nine financial ratios that were estimated to have a high level of default prediction power are used in the screening of guarantee support by the Korea Credit Guarantee Fund, a public institution that supports small and medium-sized enterprises comprehensively, were verified through discriminant analysis to determine whether there was a significant difference between the default companies and the normal companies. Between 2014 and 2016, 429 companies that took out loans with support from the Korea Credit Guarantee Fund were analyzed by using the statistical program SPSS 22 .

Findings: The nine financial ratios (capital adequacy ratio, debt to equity ratio, total borrowings to total assets, ratio of operating profit to total capitals, ratio operating profit to sales, financial cost burden ratio, total assets turnover ratio, total capitals investment efficiency, cash flow to current liabilities) were useful in combining to distinguish between default and normal companies. All nine financial ratios were significant in distinguishing between default and normal companies. The discriminant power was significant in order of financial cost burden ratio, ratio of operating profit to total capitals, ratio of operating profit to sales, capital adequacy ratio, debt to equity ratio, total borrowings to total assets, cash flow to current liabilities, total capitals investment efficiency, and total assets turnover ratio.
\end{abstract}

Improvements/Applications: This study provided a default prediction model in small and medium-sized enterprises by conducting empirical analysis of small and medium-sized enterprises. It can be said that it is meaningful to be able to use this study model as an indicator to predict the default of small and medium-sized enterprises and to proactively manage the negative impact on the national economy.

Keywords: small and medium-sized enterprise, default prediction, discriminant analysis, classification function, hit ratio, financial ratio

\section{Introduction}

In modern society, companies are facing fierce survival competition due to rapidly changing circumstances, and the risk of companies due to increased uncertainty is gradually expanding. In these circumstances, default has occurred in many forms, from large companies such as listed companies to small and medium-sized enterprises. The default has a large impact on the national economy, including the weakening of productivity, reducing employment, and reducing consumption due to the company's default, as well as numerous direct stakeholders such as employees, investors, and creditors of the company (Park, 2016). In particular, the negative impact of the default of small and medium-sized enterprises has a very large ripple effect, which can be understood from the status of small and medium-sized enterprises in the national economy. We can look at the status of small and medium-sized enterprises by the number 9983, which means that 99 percent of all companies are small and medium-sized enterprises, and 83 percent of workers work in small and medium-sized enterprises. There were many studies and empirical analysis of the default prediction model using the financial ratios of large companies, such as listed companies, but in spite of the large importance of small and medium-sized enterprises in the national economy, there was not much research on small and medium-sized 
enterprises due to lack of data, and was also limited. Most of the financing of small and medium-sized enterprises is done through loans through credit screening by banks, guarantee institutions, etc. As a result, the default of small and medium-sized enterprises initially affect the risk management crisis of banks and other financial institutions and ultimately the national economic crisis. Small and medium-sized enterprises make up the majority of companies, but there seems to be little study due to the relative size and importance of the loan size compared to large companies. In recent years, however, there has been a growing awareness that the development of small and medium-sized enterprises is of paramount importance in the development of the national economy, and the size of the loan for small and medium-sized enterprises is increasing. In the meantime, we intend to go one step further in the model of default prediction, which has been studied mainly on listed companies. Therefore, we want to develop the default prediction model of small and medium-sized enterprises using financial ratio and provide information that can be used as an indicator to reduce various losses due to default of small and medium-sized enterprises. If we can predict the default or assess the potential default in advance, the company's stakeholders will be able to take preventive measures early to prevent default or minimize the cost and economic inefficiency of the default (Song, 1999).

\section{Related Works}

\subsection{Preceding Studies in Foreign Country}

The researcher presented a model that predicted default of companies. From 1954 to 1964, 79 default companies were selected and 79 normal companies with similar asset sizes in the same industry. Analysis using financial ratios confirmed differences in 'cash flow/total liabilities', 'gross profits/total assets', 'total liabilities/total assets', 'operating capitals/total assets', 'current assets/current liabilities' between default companies and normal companies (Beaver, 1966).

The researcher selected 33 manufacturing companies filed for bankruptcy from 1946 to 1965, as well as 33 normal companies of the same and similar size. Selected financial ratio variables that were considered important indicators for the company and selected the five most predictable variables such as 'operating capitals/total assets', 'reserve profit/total assets', 'EBIT/total assets', 'market value of capital/book value of liabilities', 'sales/total assets' through the discriminant analysis (Altman, 1968).

The researcher established a model for predicting default by setting up 105 default companies and corresponding normal companies from 1970 to 1976 . It has been confirmed that the variables such as 'total liabilities/total assets', 'operating capitals/total assets', 'net profit/total assets', 'operating capitals/total liabilities', etc. are important descriptive variables (Ohlson, 1980).

The researchers selected 34 Korean listed companies that filed for bankruptcy from 1989 to 1992, and 61 normal companies with similar size in the same industry. The results of the discriminant analysis showed significant differences between the two groups in 'equity/total liabilities', 'total asset turnover ratio', and 'cash flow/total liabilities' (Altman et al., 1994).

\subsection{Preceding Studies in Korea}

The researcher selected 83 delisted companies and 83 normal companied on the KOSDAQ market from 2009 to 2012 as samples, and conducted empirical studies on the financial ratios affecting default through the logistic regression analysis and the discriminant analysis. 'Total borrowings to total assets', 'ratio of net profit to total capitals', 'financial cost burden ratio' and 'ratio of net profit to sales' were derived as significant major variables affecting the default as a result of the empirical study (Moon, 2014).

The researchers proposed a model of default prediction by responding one-to-one to 49 delisted and normal companies from 2009 to 2011. 'Ratio of operating profit to total capitals', 'ratio of net profit to total capitals', 'financial cost burden ratio', 'total borrowings to total assets', and 'net operating capital ratio' showed significant differences between normal and delisted companies (Jun and Chung, 2012).

The researcher analyzed default through the financial ratio and concluded that 'ratio of operating profit to total assets', 'ratio of net profit to total assets' and 'capital adequacy ratio' are important for predicting default companies (Lee, 2015).

\section{Materials and Methods}

\subsection{Selecting of Sample Company}

Most of the previous studies on default predictions analyzed large listed companies, and the number of samples was not large. There seems to be a limit to applying default prediction models and variables for large companies to small and medium-sized enterprises. Therefore, this study was sampled by delisted small and medium-sized enterprises that took 
out loans through the guarantee of the Korea Credit Guarantee Fund, a comprehensive financial institution for small and medium-sized enterprises. Small and medium-sized enterprises have large deviations of financial ratios by company size and industry, which can lead to distorted results for all small and medium-sized enterprises. Therefore, in order to reduce this deviation, only small and medium-sized manufacturing enterprises with similar company size were selected as samples from external audited companies that can secure the reliability of their financial statements.

\subsection{Selecting Variables}

A total of 9 financial ratios[Table 1] that are estimated to be have a high level of default predictive power as used by the Korea Credit Guarantee Fund to screen guarantee support were verified through discriminant analysis to determine whether there were significant differences between the default and the normal companies. Between 2014 and 2016, 429 companies that took out loans with support from the Korea Credit Guarantee Fund were analyzed by using the statistical program SPSS 22. Of the 429 companies, 363 were normal until the maturity of loans, while 66 were default before the maturity of loans (the maturity of loan is from 2017 to 2019).

Table 1. Operational definitions of variables

\begin{tabular}{|c|c|}
\hline Variables & Operational definition \\
\hline Capital adequacy ratio & $\{$ Capital / (debt +capital) $\} * 100$ \\
\hline Debt to equity ratio & $($ Debt /capital) $* 100$ \\
\hline Total borrowings to total assets & $\begin{array}{l}\{\text { Total borrowed money / (total borrowed money }+ \\
\text { capital)*100 }\end{array}$ \\
\hline Ratio of operating profit to total capitals & $\{$ Operating profit / (debt +capital) $\} * 100$ \\
\hline Ratio of operating profit to sales & (Operating profit / sales)*100 \\
\hline Financial cost burden ratio & $($ Interest cost / sales)*100 \\
\hline Total assets turnover ratio & Sales / total assets \\
\hline Total capitals investment efficiency & $\begin{array}{l}\text { \{Value added } / \text { (total assets of former period }+ \text { total assets of } \\
\text { current period) } / 2\} * 100\end{array}$ \\
\hline Cash flow to current liabilities & $\begin{array}{l}\{\text { (Net income }+ \text { depreciation cost }+ \text { amortization cost of } \\
\text { intangible asset }) / \text { current liabilities }\} * 100\end{array}$ \\
\hline
\end{tabular}

\section{Empirical Analysis}

\subsection{Research Project}

Through the determinant analysis using Statistics program SPSS 22, we want to examine whether 9 financial ratios of 'capital adequacy ratio', 'debt to equity ratio', 'total borrowings to total assets', 'ratio of operating profit to total capitals', 'ratio of operating profit to sales', 'financial cost burden ratio', 'total assets turnover ratio', 'total capitals investment efficiency, and 'cash flow to current liabilities' are useful in distinguishing default and normal companies in combination. In addition, we want to examine which financial ratios are significant in discriminant power and which ones have large discriminant power.

\subsection{Statistical Analysis}

Table 2 represents mean and standard deviation of the 9 variables of each group. 'Capital adequacy ratio', 'ratio of operating profit to total capitals', 'ratio of operating profit to sales', 'total assets turnover ratio', 'total capitals investment efficiency', 'cash flow to current liabilities' were higher in group 2 than in group 1 and the remaining variables were higher in group 1 than in group 2 (Hajdari, 2018); (Handika and Ekananda, 2019). 
Table 2. Group statistics

\begin{tabular}{llrrrr}
\hline & & \multicolumn{2}{c}{ St. } & \multicolumn{2}{c}{ Valid N (listwise) } \\
\cline { 5 - 6 } Classifying & & Mean & Deviation & Unweighted & Weighted \\
\hline The group & Capital adequacy ratio & 28.20198 & 8.44281 & 66 & 66.000 \\
of default & Debt to equity ratio & 286.60295 & 118.83549 & 66 & 66.000 \\
companies & Total borrowings to total assets & 63.86217 & 8.94293 & 66 & 66.000 \\
(Group 1) & Ratio of operating profit to total capitals & 2.96502 & 2.22268 & 66 & 66.000 \\
& Ratio of operating profit to sales & 2.57479 & 2.12020 & 66 & 66.000 \\
& Financial cost burden ratio & 2.63260 & 2.04728 & 66 & 66.000 \\
& Total assets turnover ratio & 1.23556 & .50041 & 66 & 66.000 \\
& Total capitals investment efficiency & 24.08815 & 10.53595 & 66 & 66.000 \\
& Cash flow to current liabilities & 14.05842 & 10.38333 & 66 & 66.000 \\
\hline The group & Capital adequacy ratio & 31.12622 & 10.07816 & 363 & 363.000 \\
of normal & Debt to equity ratio & 253.96347 & 110.50130 & 363 & 363.000 \\
companies & Total borrowings to total assets & 60.42502 & 12.25080 & 363 & 363.000 \\
(Group 2) & Ratio of operating profit to total capitals & 4.91789 & 4.88349 & 363 & 363.000 \\
& Ratio of operating profit to sales & 3.65710 & 3.20665 & 363 & 363.000 \\
& Financial cost burden ratio & 2.01248 & 1.07353 & 363 & 363.000 \\
& Total assets turnover ratio & 1.45150 & .85985 & 363 & 363.000 \\
& Total capitals investment efficiency & 27.32180 & 12.38557 & 363 & 363.000 \\
& Cash flow to current liabilities & 20.62072 & 25.54607 & 363 & 363.000 \\
\hline
\end{tabular}

Table 3 shows the results of difference verification (ANOVA). The results of difference verification between the two groups showed significant differences in all variables. Of the nine variables, the financial cost burden ratio represents the smallest Wilks' lambda and the largest F value. This means that the discriminant power of financial cost burden ratio is the highest in general. In other words, the difference between the two groups is the largest in the financial cost burden ratio.

Table 3 . Tests of equality of group means

\begin{tabular}{lrrrrr}
\hline & Wilks' Lambda & \multicolumn{1}{c}{ F } & df1 & df2 & Sig. \\
\hline Capital adequacy ratio & .989 & 4.925 & 1 & 427 & .027 \\
Debt to equity ratio & .989 & 4.759 & 1 & 427 & .030 \\
Total borrowings to total assets & .989 & 4.733 & 1 & 427 & .030 \\
Ratio of operating profit to total capitals & .977 & 10.156 & 1 & 427 & .002 \\
Ratio of operating profit to sales & .984 & 6.958 & 1 & 427 & .009 \\
Financial cost burden ratio & .970 & 13.297 & 1 & 427 & .000 \\
Total assets turnover ratio & .991 & 3.916 & 1 & 427 & .048 \\
Total capitals investment efficiency & .991 & 3.974 & 1 & 427 & .047 \\
Cash flow to current liabilities & .990 & 4.222 & 1 & 427 & .041 \\
\hline
\end{tabular}

We can find information about the canonical discriminant function in Table 4. The table below shows the result of Wilks' lambda and $\chi^{2}$ verification. $\chi^{2}$ verification is to verify whether there is a difference between the two groups across the variables. At this time, the null hypothesis $\left(\mathrm{H}_{0}\right)$ is as follows:

$\mathrm{H}_{0}$ : The average of all variables is the same across the group. 
The verification results were significantly shown as $\mathrm{p}=0.007$. Therefore, 9 financial ratios can be said to be useful in distinguishing between the default and the normal companies in combination.

Table 4. Wilks' Lambda

\begin{tabular}{lrrrrr}
\hline Test of Function (s) & Wilks' Lambda & Chi-square & Df & \multicolumn{2}{c}{ Sig. } \\
\hline 1 & .948 & 22.726 & 9 & .007 \\
\hline
\end{tabular}

Table 5 represents standardized canonical discriminant function coefficients. This coefficient is a standardized coefficient, indicating the relative importance of each variable in explaining the group of default and normal companies. In this case, the financial cost burden ratio appeared to be the most important variable with the greatest discriminant power.

Table 5. Standardized canonical discriminant function coefficients

\begin{tabular}{lr}
\hline & \multicolumn{2}{c}{ Function } \\
\cline { 2 - 2 } & \multicolumn{1}{c}{1} \\
\hline Capital adequacy ratio & .105 \\
Debt to equity ratio & .546 \\
Total borrowings to total assets & .191 \\
Ratio of operating profit to total capitals & .027 \\
Ratio of operating profit to sales & -.534 \\
Financial cost burden ratio & .691 \\
Total assets turnover ratio & -.201 \\
Total capitals investment efficiency & .021 \\
Cash flow to current liabilities & -.056 \\
\hline
\end{tabular}

The structure matrix shown in Table 6 shows a correlation between each variable and the standardized canonical discriminant function. Here, the correlation between the financial cost burden ratio and the discriminant function was also shown to be the highest. Discriminant loading on the structure matrix showing the correlation value between the discriminant functions is more useful for determining the discriminant power than standardized canonical discriminant function coefficients. Discriminant loading is usually accepted significantly if more than \pm 0.40 (Hair et al., 2010). Therefore, discriminant power was significant in order of financial cost burden ratio, ratio of operating profit to total capitals, ratio of operating profit to sales, capital adequacy ratio, debt to equity ratio, total borrowings to total assets, cash flow to current liabilities, total capitals investment efficiency, total asset turnover ratio.

Table 6. Structure matrix

\begin{tabular}{lr}
\hline & \multicolumn{2}{c}{ Function } \\
\cline { 2 - 2 } & \multicolumn{1}{c}{1} \\
\hline Financial cost burden ratio & .751 \\
Ratio of operating profit to total capitals & -.656 \\
Ratio of operating profit to sales & -.543 \\
Capital adequacy ratio & -.457 \\
Debt to equity ratio & .449 \\
Total borrowings to total assets & .448 \\
Cash flow to current liabilities & -.423 \\
Total capitals investment efficiency & -.410 \\
Total assets turnover ratio & -.407 \\
\hline
\end{tabular}


Table 7 shows the classification function coefficients. Using these coefficients, we derived classification functions between each group.

$$
\begin{gathered}
\text { Classification function of group } 1 \\
=7.042 * \mathrm{X}_{1}+0.304 * \mathrm{X}_{2}+3.339 * \mathrm{X}_{3}+0.276 * \mathrm{X}_{4}+0.272 * \mathrm{X}_{5}-0.018 * \mathrm{X}_{6}+3.483 * \mathrm{X}_{7}+0.153 * \mathrm{X}_{8}-0.333 * \mathrm{X}_{9}-252.503 \\
\text { Classification function of group } 2
\end{gathered}
$$

Group 1: the group of default companies, Group 2: the group of normal companies.

$\mathrm{X}_{1}$ : capital adequacy ratio, $\mathrm{X}_{2}$ : debt to equity ratio, $\mathrm{X}_{3}$ : total borrowings to total assets, $\mathrm{X}_{4}$ : ratio of operating profit to total capitals, $\mathrm{X}_{5}$ : ratio of operating profit to sales, $\mathrm{X}_{6}$ : financial cost burden ratio, $\mathrm{X}_{7}$ : total assets turnover ratio, $\mathrm{X}_{8}$ : total capitals investment efficiency, $X_{9}$ : cash flow to current liabilities (Harianja and Fibriasari, 2019); (Haryana and Mulyana, 2019).

Using the above two classification functions, it is possible to predict which group belongs to. Classification objects are classified in a group that appears as a large value as a result of the calculation by inserting the variable values of the classification object into the classification function.

Table 7. Classification function coefficients (Fisher's linear discriminant functions)

\begin{tabular}{lrr}
\hline & \multicolumn{2}{c}{ Classification } \\
\cline { 2 - 3 } & Group 1 & \multicolumn{1}{c}{ Group 2 } \\
\hline Capital adequacy ratio & 7.042 & 7.035 \\
Debt to equity ratio & .304 & .300 \\
Total borrowings to total assets & 3.339 & 3.349 \\
Ratio of operating profit to total capitals & .276 & .272 \\
Ratio of operating profit to sales & .272 & .385 \\
Financial cost burden ratio & -.018 & -.371 \\
Total assets turnover ratio & 3.483 & 3.643 \\
Total capitals investment efficiency & .153 & .152 \\
Cash flow to current liabilities & -.333 & -.332 \\
(Constant) & -252.503 & -251.822 \\
\hline
\end{tabular}

Table 8 shows how well the classification function predicts a total of 429 companies that have been analyzed statistically. Of the 66 default companies, 47 were correctly classified, and 254 of the 363 normal companies were classified correctly. Overall, 301 of the 429 were accurately classified, and the hit ratio was $70.2 \%$.

Table 8. Classification results

\begin{tabular}{llrrrr}
\hline \multirow{2}{*}{ Classification } & & \multicolumn{2}{c}{ Predicted Group Membership } & \\
\cline { 3 - 5 } & & & Group 1 & Group 2 & \multirow{2}{*}{ Total } \\
\hline Original & Count & Group 1 & 47 & 19 & 66 \\
& & Group 2 & 109 & 254 & 363 \\
\cline { 2 - 5 } & $\%$ & Group 1 & 71.2 & 28.8 & 100.0 \\
& Group 2 & 30.0 & 70.0 & 100.0 \\
\hline
\end{tabular}




\section{Conclusion}

In this study, we examined the default prediction model of small and medium-sized enterprises. We conducted an empirical analysis on the 9 financial ratios used in the screening of guarantee support by the Korea Credit Guarantee Fund, a comprehensive support institution for small and medium-sized enterprises. As a result, it was confirmed that all nine financial ratios used in this study are significant variables in distinguishing between default and normal companies. In the meantime, there has been a lot of research on default prediction models for large companies, such as listed companies, but research on small and medium-sized enterprises that have been having a significant impact on the national economy due to lack of data was insufficient. This study provided a default prediction model in small and medium-sized enterprises by conducting empirical analysis of small and medium-sized enterprises. It can be said that it is meaningful to be able to use this study model as an indicator to predict the default of small and medium-sized enterprises and to proactively manage the negative impact on the national economy. The indicators used in this study correspond to a fraction of the various financial ratios, and the financial ratios alone are bound to show limits on predictive power. Therefore, in order to overcome the limitations of financial ratios, which are traditional quantitative indicators, it is expected that an analysis will be needed to improve the accuracy of default prediction by utilizing additional qualitative indicators such as the management skills of entrepreneurs.

\section{Acknowledgment}

This research was financially supported by Hansung University.

\section{References}

Altman, E. I. (1968). Financial ratios discriminant analysis and the prediction of corporate bankruptcy. Journal of Finance, 23(4), 589-609.

Altman, E. I., Eom, Y. H., \& Kim, D. W. (1994). Classification Distress of Korean firm.

Beaver, W. H. (1966). Financial ratios as predictors of failure. Journal of Accounting Research, 4(3), 71-111.

Hair, J. F., Black, W. C., Babin, B. J., \& Anderson, R. E. (2010). Multivariate data analysis (7th ed.). Pearson, p. 309.

Hajdari, A. (2018). Avoidance and withdrawal from criminal Prosecution-Kosovo context. International Journal of Social Sciences and English Literature, 2, 7-12.

Handika, R., \& Ekananda, M. (2019). Benefits and consequences of diversification: Evidence from financialzed commodity portfolios. Asian Business Research Journal, 4, 17-28.

Harianja, N., \& Fibriasari, H. (2019). Youtube as the learning media to improve the speaking skill in expression orale course. Asian Themes in Social Sciences Research, 3(1), 14-17.

Haryana, R., \& Mulyana, B. (2019). Optimal stock portfolio issuers of building construction registered in LQ45 based on the Markowitz approach. The Economics and Finance Letters, 6(1), 100-109.

Jun, H. W., \& Chung, Y. H. (2012). An empirical study on the failure prediction model of delisting firms in KOSDAQ market. The Journal of Business Education, 26(1), 93-106. Retrieved from https://www.earticle.net/Article/A167716

Lee, J. U. (2015). Financial stability evaluation and implications through recent corporate sector solvency analysis. KIF Research, 2015(3), 1-76. Retrieved from http://www.papersearch.net/thesis/article.asp?key=3309882

Moon, J. K. (2014). An empirical study on the failure prediction of the manufacturing firms in KOSDAQ [dissertation]. South Korea: Hoseo University. Retrieved from http://hoseo.dcollection.net/public_resource/pdf/000001908701_20200226210452.pdf

Ohlson, J. A. (1980). Financial ratios and the probabilistic prediction of bankruptcy. Journal of Accounting Research, 18(1), 109-131.

Park, B. K. (2016). Usefulness of the interesting coverage ratio as a predictor of bankruptcy unlisted companies [master's thesis]. South Korea: Pusan National University. Retrieved from http://www.riss.kr/link?id=T14194428

Song, D. S. (1999). An empirical study on the Estimate information of business failure. Journal of Tax Accounting Research, 391-416. Retrieved from http://www.papersearch.net/thesis/article.asp?key=2222041 